\section{ADDITIONAL RECORDS OF ICHTHYOPHIS BOMBAYENSIS TAYLOR, 1960 IN AND AROUND DANGS, GUJARAT}

\author{
Bonny Pilo ${ }^{1}$, E. Manoj ${ }^{1}$, Shilpa Dhuru ${ }^{2}$ and \\ Manju Siliwal ${ }^{3}$
}

1, 2 Department of Zoology, Faculty of Science, M.S. University of Baroda, Vadodara, Gujarat 390002, India

${ }^{3}$ Corresponding author; Wildlife Information \& Liaison Development Society, 29/1, Bharathi Colony, Peelamedu, Coimbatore, Tamil Nadu 641004, India

Email: ${ }^{1}$ bonnypilo@satyam.net.in, ${ }^{2}$ shilpa dhuru@hotmail.com, 3 manjusiliwal@rediffmail.com

web supplement

A recent publication on distribution of Ichthyophis bombayensis Taylor, 1960 was published by Vyas (2004) lists collection data from three districts in Gujarat -- Dangs, Navsari and Surat. As part of the "Conservation of the Rare and Endangered Biodiversity of Gujarat" (CREB) project sponsored by Gujarat Ecological Commission, our team recorded this species in parts of Dangs, Navsari and Valsad districts.

Preliminary survey about the presence or absence of this species in the study area was carried out through questionnaires. Next, selected road stretches were chosen to check for the presence of Ichthyophis sp. for the next seven nights from 10 to 16 June 2001 (Table 3). Each night, select stretches of roads passing through varied habitats in the study area were surveyed using a vehicle moving at a steady speed of $20-30 \mathrm{~km} / \mathrm{h}$ (Table $1 \& 3$ ) and about $1,500 \mathrm{~km}$ were covered during the survey period. Width of the road varied between 6 to $9 \mathrm{~m}$. During the survey, the team comprising of eight members used four powerful torches $(300 \mathrm{~V})$ and vehicle headlights to scan the road thoroughly for the presence of Ichthyophis sp.

When a specimen was sighted, it was identified following Taylor (1961), Bhatta (1998) and, Pillai and Ravichandran (1999). The surrounding areas with all probable habitats of the taxon such as under logs and stones, debris, decomposing leaf litter, beneath the top layer of soil and, near seasonal and perennial water bodies were thoroughly searched for the presence of more individuals. Separate records of live and dead specimens encountered in each road transect were maintained (Table 1). Ecological parameters like temperature, humidity, habitat description and characteristics were noted down for each dead or live animal encountered during the survey. A few roadkill specimens were collected for species confirmation. They are deposited with M.S. University, Department of Zoology Museum, under the charge of Dr. B. Suresh. The team did not record morphometric measurements of live specimens. Morphometry of all dead specimens was not possible as they were either badly damaged or decayed. Only two roadkills in relatively good condition were measured.

Morphometric measurements of the two roadkill specimens are presented in Table 2. The maximum number of individuals were sighted on Navtad-Ahwa-Navtad route $(180 \mathrm{~km})$. Considering the rarity of this animal, the numbers encountered during the present study are very significant. The subterranean habit of this animal makes it difficult to estimate their actual numbers. All the individuals were sighted in a span of seven days during the first monsoon showers in the study area.

Habit and habitat: The habitat in all the 11 localities, where Ichthyophis bombayensis were found was moist deciduous forest patches interspersed with agricultural lands. Daniel (1963), Bhatta (1997, 1998), Hofer (2000), and, Vyas (2004) report the presence of Ichthyophis sp. from varied microhabitats including under rocks, fallen tree trunks, decaying vegetation, dilapidated houses, under hayracks, dumping areas, cleared land used for paddy cropping, coffee and tea plantations.

Out of the 32 sightings of Ichthyophis bombayensis, 18 were on roads passing through the forests, of which five individuals were found near Kilaad Village that had paddy fields on one side and forest patches of Vansda National Park (VNP) on the other. At Pimpri, Kilaad, Chichigoantha, Ichthyophis bombayensis was observed entering decaying vegetation, under rocks and in paddy fields, respectively. Live individuals of Ichthyophis bombayensis were sighted on roads only during nights after heavy rains or during continuous drizzle between $2000 \mathrm{~h}$ and $0200 \mathrm{~h}$ but maximum individuals (seven) were observed between 2100 to $2200 \mathrm{~h}$. Even when the roads were wet without drizzle, the animals could not be seen on the road indicating that continuous wet surface was preferred in order to move out of the burrows to feed or migrate from one place to another. Vijaykumar et al. (2001) also observed that caecilians are found more on rainy nights.

Threats: Eighteen dead individuals (roadkills) of Ichthyophis bombayensis were observed from 11 localities of study area (Images $1 \& 2^{\mathrm{w}}$, Table 1). As State Highways number 14 and 15 pass through the villages Kilaad and Waghai (adjoining the Vansda National Park area), they could be considered one of the major threats to Ichthyophis bombayensis in this region.

Srinivasulu et al. (1995) and Vijaykumar et al. (2001) have also reported vehicular traffic as a major threat to herpetofauna including caecilians in semi urban and forested tracts of southern India. Vijaykumar et al. (2001) in their study say that because the caecilians are found commonly in roadkills in coffee plantations, probably they are more adapted to habitat alterations. We do not agree with them in this view as we feel that natural forest provide better habitat condition for caecilians and therefore are seldom seen. We do agree with them that vehicular traffic/ roadkill can deplete local herpetofauna population.

Furthermore, Bhatta et al. (1998) and Hofer (2000) reported change in the soil $\mathrm{pH}$ from acidic to alkaline due to the use of lime as fertilizer as one of the reasons for the decline in the population of Ichthyophis sp. in cultivable land. However, such change in soil $\mathrm{pH}$ (acidic to alkaline) was not found to be a threat in our study area because the tribals still practice traditional methods of agriculture, without use of artificial chemicals.

${ }^{w}$ see Image $1 \& 2$ on the web at www.zoosprint.org 


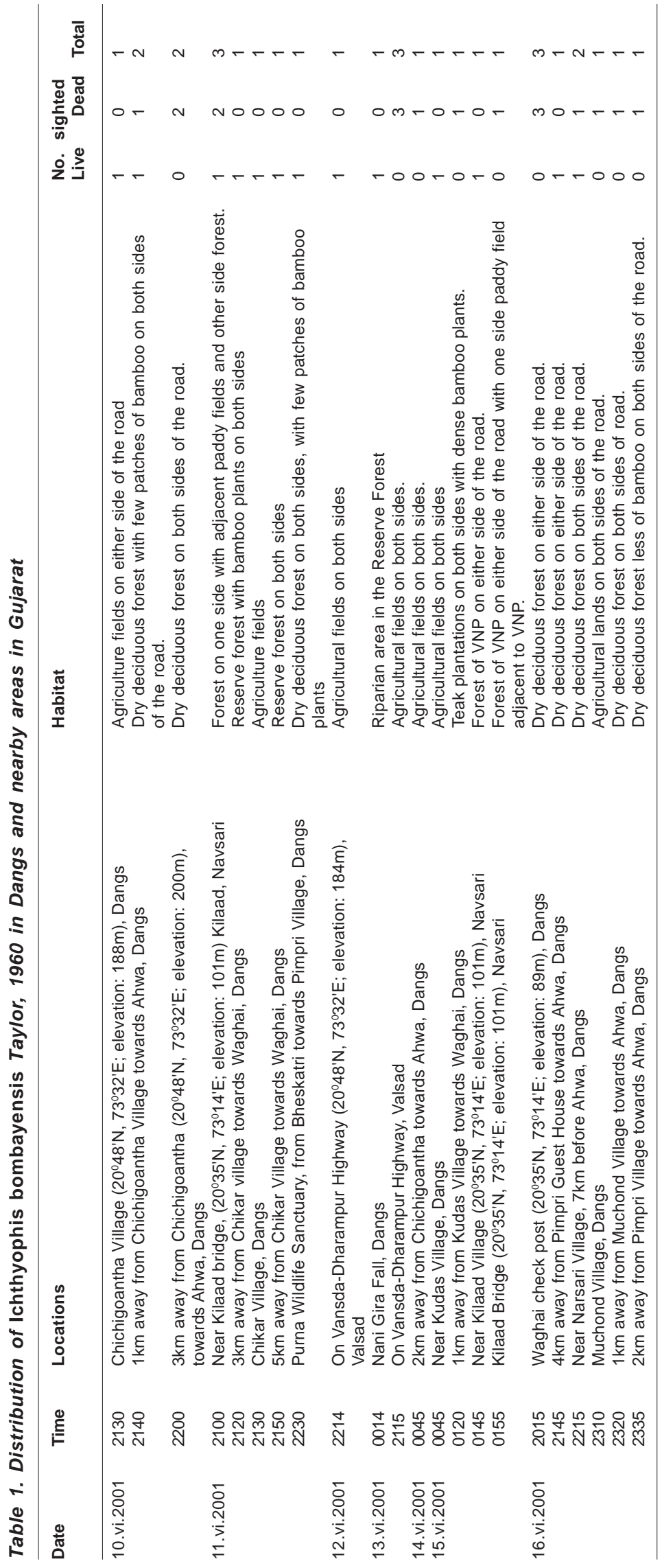

Owing to the paucity of information on this taxon, further intensive studies relating to its systematic, anatomical, histological, ecological, behavioral and phylogenetic aspects are urgently needed. Any added information would certainly help us understand this taxon much better.

\section{REFERENCES}

Bhatta G.K. (1997). Caecilian diversity of the Western Ghats: In search of the rare animals. Current Science 73(2): 183-187.

Bhatta G.K. (1998). A field guide to the Cecilians of the Western Ghats, India. Journal of Bioscience 23(1): 73-85. Bhatta, S., P.V. Desai, S. Katre, S.V. Krishnamurthy, S.S. Kamble, M.S. Ravichandran, S. Bhupathy, R. Gupta, S.C. Despande, and A. Kumar (1998). Ichthyophis bombayensis Taxon Data Sheet, pp.57-58. In: Molur S. and S. Walker (Eds.). Report of the workshop Conservation Assessment and Management Plan for Amphibians of India (BCCP Endangered Species Project) Zoo Outreach organisation, CBSG India, Coimbatore,

Daniel, J.C. (1963). Field guide to the Amphibians of Western India. Part 1. Journal of Bombay Natural History Society 60(2): 429-430.

Hofer, D. (2000). A short note about the status and abundance of Ceacilian populations. Froglog 42: 1.

Pillai, R.S. and M.S. Ravichandran (1999). Gymnophiona (Amphibian) of India - A taxonomic study. Records of Zoological Survey of India, Occasional Paper No. 172: 166pp.

Srinivasulu, C., B. Srinivasulu, V. Nagulu, and V.V. Rao (1995). Faunal mortality on a selected stretch of National Highway No. 7 passing through suburban Secunderabad, Andhra Pradesh. Journal of Zoological Society of Kerala 5(1\&2): 79-82.

Taylor, E.H. (1960). On the caecilian species Ichthyophis monochrous and Ichthyophis glutinosus with description of related species. University of Kansas Science Bulletin 40(4):37-120.

Taylor, E.H. (1961). Notes on Indian Ceacilians. Journal of Bombay Natural History Society 58(2): 355-365.

Vijaykumar, S.P., K. Vasudevan and N.M. Ishwar (2001). Herpetofaunal mortality on roads in the Anamalai Hills, Southern Western Ghats. Hamadryad 26(2): 253-260.

Vyas, R. (2004). Notes on the distribution and natural history of Ichthyophis bombayensis (Gymnophiona: Ichthyophiidae). Hamadryad 28(1\&2): 130-136.

\section{ACKNowledgement}

Authors are thankful to Gujarat Ecology Commission for the project on "Conservation of the Rare and Endangered Biodiversity of Gujarat" under which this study was carried out. Authors are also thankful to Mr. Anil Johari (Conservator of Forests, Surat Circle), Mr. Mukesh Kumar and Ram Kumar (Dy. Conservator of Forests, North \& South Dangs) and Mr. M.P. Joshi (RFO, Vansda National Park) for their help and guidance during the study. We are grateful to Drs. C. Srinivasulu and B. Srinivasulu, Research Associates, Osmania University, Hyderabad and Mr. Sanjay Molur, Deputy Director, Zoo Outreach Organisation for critical comments on the manuscript. We extend our sincere thanks to Prof. Y.M. Naik, Department of Zoology, M.S. University, Vadodara for accompanying us in the field and also helping us in the identification of the species. We also acknowledge Dr. G. K. Bhatta for assisting us in identifying the species. 


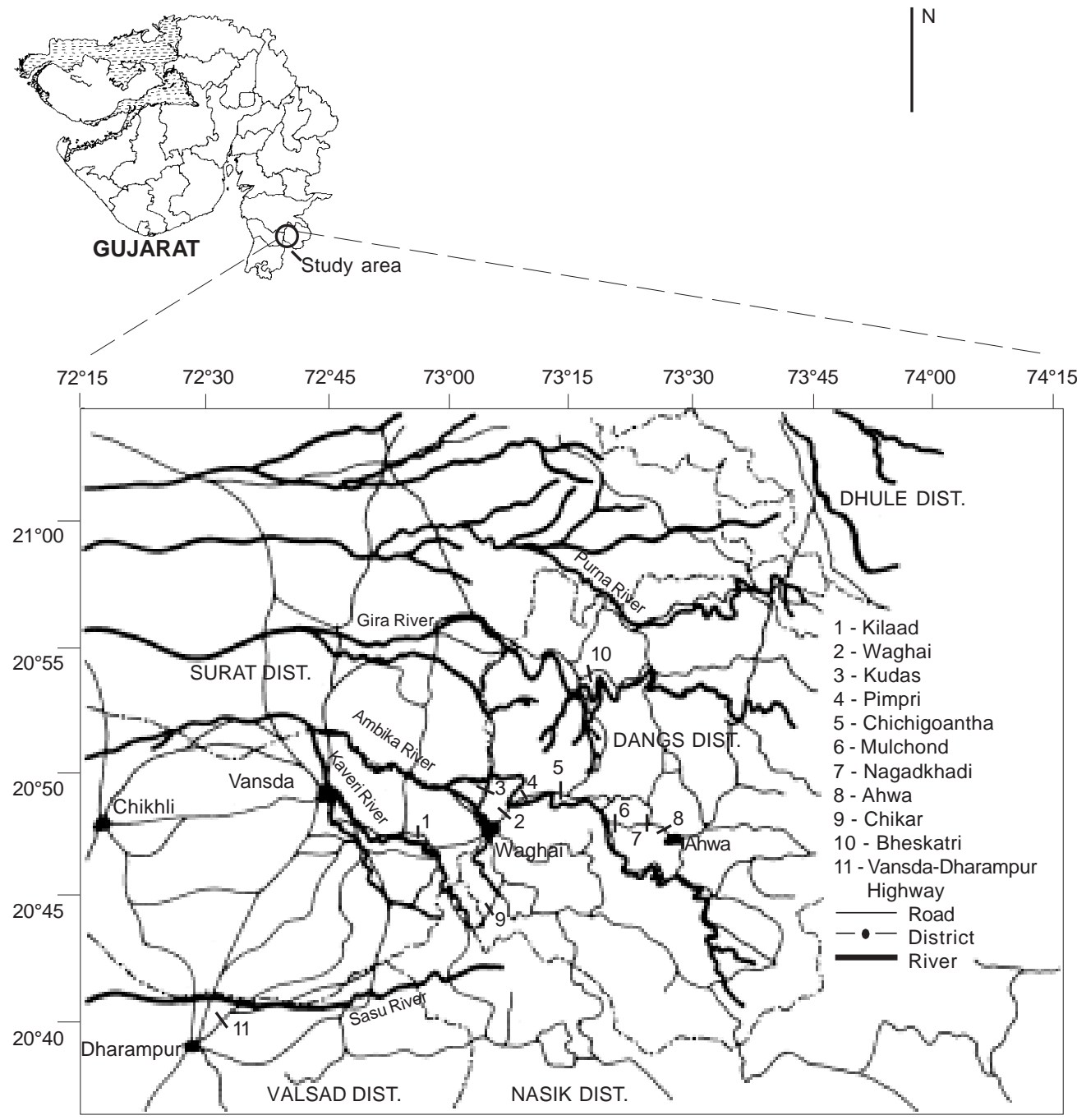

Figure 1. Localities where Ichthyophis bombayensis was found in the study area.

Table 2. Morphometric measurements (in $\mathrm{mm}$ ) of two specimens of Ichthyophis bombayensis Taylor, 1960

\begin{tabular}{|c|c|c|}
\hline Parameters & MSU-AMP-23-1w & MSU-AMP-23-2 \\
\hline Total length & 370 & 415 \\
\hline Tail length & 15 & 18 \\
\hline Head width & 12 & 14 \\
\hline Snout length & 15 & 18 \\
\hline Body width & 15 & 16 \\
\hline Eye to tentacle & 3 & 3 \\
\hline Tentacle to nostril & 5.2 & 4 \\
\hline Eye to nostril & 6.0 & 6 \\
\hline Eye to eye & 9 & 9 \\
\hline Snout tip to $1^{\text {st }}$ groove & 16 & 19 \\
\hline Snout tip to $2^{\text {nd }}$ groove & 20 & 23 \\
\hline Snout tip to $3^{\text {rd }}$ groove & 25 & 28 \\
\hline Body folds & 356 & 380 \\
\hline Tail folds & 17 & 17 \\
\hline Premaxillary-maxillary & - & - \\
\hline Prevemeropalatine & - & - \\
\hline Dentary & - & - \\
\hline Splenial & $9-9$ & $9-9$ \\
\hline
\end{tabular}

'- We were unable to count the number of teeth because the head of the specimen was not in good condition.
Table 3. Road route for the night survey in Dangs and nearby areas

\begin{tabular}{lllll}
\hline Date & Road route & $\begin{array}{l}\text { D } \\
(\mathbf{k m})\end{array}$ & No. Survey Time \\
\hline 10.vi.01 & $\begin{array}{l}\text { Navtad-Pimpri-Ahwa-Pimpri-Navtad } \\
\text { 11.vi.01 }\end{array}$ & 180 & 5 & 1930 to 0300h \\
$\begin{array}{l}\text { Navtad-Chikar-Waghai-Bheskatri } \\
\text { Purna WLS Sanctuary)-Navtad }\end{array}$ & 240 & 7 & 2000 to 0430h \\
12.vi.01 Navtad-Dharmpur-Navtad & 310 & 1 & 1900 to 0400h \\
13.vi.01 Navtad-Nani Gira Fall-Chikar-Waghai- & & & \\
$\quad$ Navtad-Dharampur-Navtad & 360 & 4 & 2000 to 0530h \\
14.vi.01 Navtad-Pimpri-Ahwa-Pimpri-Navtad & 180 & 1 & 2100 to 0500h \\
15.vi.01 Navtad-Chichinagaotha-Navtad & 115 & 4 & 2030 to 0300h \\
16.vi.01 Navtad-Pimpri-Ahwa-Pimpri-Navtad & 180 & 10 & 1930 to 0445h \\
\hline D - Distance travelled; No. - Number of I. bombayensis sighted
\end{tabular}

${ }^{w}$ see photo image of specimen MSU-AMP-23-1 on the web at www.zoosprint.org 